\title{
CORRESPONDENCE
}

\section{Geothermal power}

SIR-The recent News and Views article by Richardson and White (Nature 10 July) ${ }^{1}$ and correspondence in your columns ${ }^{2}$ have been concerned with the relative merits of two ways of using geothermal energy - district heating and electricity generation - and there does not seem to be much to choose between them. According to Richardson and White, "Neither of the schemes is particularly attractive in absolute terms". Certainly, electricity generation directly from a geothermal source at a temperature below $200^{\circ} \mathrm{C}$ has previously been considered to be uneconomic ${ }^{3,4}$.

It was because of this view that Patscentre, some three years ago, proposed a scheme that allowed the possible exploitation of such lowtemperature geothermal sources for economical electricity generation if they coincided with sites for conventional power stations, existing or prospective $e^{5}$. Geothermal hot water could be efficiently used for feedwater heating in the power stations. I suggested that such a concidence of sites might be found on the Hampshire (geological) sedimentary basin. The idea was taken up by the Central Electricity Generating Board, and a borehole was sunk last year at Marchwood power station, near Southampton. Earlier this year, you reported that an aquifer had been struck (Nature, 8 May) $^{6}$. I understand that the geothermal hot water will probably be used in the Marchwood station as an experimental illustration of the proposed scheme.

It is to be hoped that, if successful, this experiment will be the forerunner of an acceptably efficient method of geothermal electricity generation in the UK and elsewhere.

PA Centre for Advanced Studies,

R.V. HARROWELL

Melbourn, Cambridge, UK

1. Richardson, S.W. \& White, A.A.L. Nature 286, 103-104 (1980)

2. Garish, J.D. Nature 286, 326 (1980)

3. Oxburgh, E.R. Nature 262, 526 (1976)

4. Gliddon, B.J. et al. CEGB Research, no. 2, 40 (1975).

. Harrowell, R.V. Nature 266, 299 (1977).

6. Nature 285, 64 (1980).

SIR - The method of evaluation for the district heating option used by Richardson and White in their article on the use of UK geothermal energy resources (Nature 10 July, p.103) is not appropriate for UK geothermal resource conditions.

The Department of Energy Geothermal Energy Group have predicted that geothermal energy sedimentary basin resources in the United Kingdom will be most commonly in the range 65 to $80^{\circ} \mathrm{C}$. We have recently completed a study for the Department of Energy examining the use of UK geothermal energy resources which concluded that a supply temperature of $65^{\circ} \mathrm{C}$ will be adequate to meet space and water heating needs. Underfloor heating systems or large natural convectors could operate with a supply temperature of $65^{\circ} \mathrm{C}$ to satisfy comfort conditions and achieve a return temperature of $30-35^{\circ} \mathrm{C}$. We believe, however, that the optimum solution will arise from forced air convection equipment which could reduce the return water temperature to the geothermal source heat exchanger to $20-25^{\circ} \mathrm{C}$ and furthermore a proposal is in hand directed by W.S. Atkins and Partners and supported by a major UK heating equipment manufacturer to develop a range of such equipment at competitive price levels

when compared to standard temperature equipment.

A further important factor to be considered is that the depth of aquifers containing brine at $70^{\circ} \mathrm{C}$ is such that it could significantly reduce the cost of the geothermal well compared to an aquifer supplying water at $100^{\circ} \mathrm{C}$. We suggest therefore that the findings of Richardson and White be reconsidered.

E. J. Athony

Environmental Engineering Division,

W. S. Atkins \& Partners, Epsom, UK

\section{Models of psychosis}

SIR-In a recent News and Views article (Nature, 5 June)', Snyder expressed the view that phencyclidine - currently all the rage among drug-abusers in the United States might provide a good pharmacological model of schizophrenia. In the course of his paper he makes a comparison with LSD-25 which, he suggests, is not a good model because it produces perceptual disturbances that are mainly visual in nature, whereas those found in schizophrenia occur primarily in the auditory modality. There is actually no factual basis for that statement; on the contrary, several studies (for example, Young ${ }^{2}$ ) indicate that the effects of LSD on perceptual, as well as on other psychological, functions, are remarkably similar to the symptoms of schizophrenia. This widely quoted misconception about LSD is only one of many which have led, in my view, to the drug being prematurely rejected as a possible pharmacological model for human psychosis. As I have argued in detail elsewhere ${ }^{3}$, I believe a good case can still be made for LSD; though Snyder may be right - phencyclidine may be better.

G.S. Claridge

Department of Experimental Psychology,

University of Oxford, $U K$

1. Snyder, S.H. Nature 285, 355-356 (1980)

2. Young, B.J. Br. J. Psychiat 124, 64-73 (1974).

3. Claridge, G.S. Schiz. Bull. 4, 186-209 (1978).

\section{Educative computers}

SIR - We were very interested to read your article "Money to spend" (Nature 21 August, p.750) about the government's programme on microelectronics in schools and colleges.

One matter of fact, however, we feel should be put right. The estimate of about one hundred schools owning their own computers is a long way off the mark. A survey carried out in the first three months of the year by ourselves and the Schools Council, in which replies were received from 60 out of 104 local education authorities in England and Wales, showed 663 secondary schools with at least one microcomputer. (In Scotland, the figure at the end of August was over 250.)

Even those figures should be taken as very conservative estimates since numbers are growing rapidly from day to day. We know of one local authority, for instance, which is installing a new machine at its schools at the rate of one a week.

If any of your readers would be interested to have a copy of a brief report of our survey referred to above, we should be pleased to send them one. JiLl COATES Council for Educational Technology, 3 Devonshire Street, London WIN $2 B A$

\section{Interferonology}

SIR - I am writing in response to the note on interferon nomenclature which appeared recently in Nature (10 July 1980; 286, 110).

I recognize that the previous nomenclature is less than ideal because the names ("leukocyte", "ffibroblast" etc.) now refer to molecular classes of interferons rather than tissues of origin.

With the foregoing qualification in mind, what is gained by replacing $\mathrm{L}, \mathrm{F}$ and $\mathrm{T}$ with $\alpha$, $\beta$ and $\gamma$ ? If physicists changed the names of the $u, d, s$ and $c$ quarks, let us say, to $x, y, z$ and $t$, absolutely nothing would be gained except the additional complication of memorizing which is which. Fortunately, most physicists, unlike most interferonologists, are aware that such symbols are merely arbitrary denotations for distinct entities and are in themselves meaningless. (As long as there are three interferons, why not Athos, Pothos and Aramis? D'Artagnon would be available if another were discovered.)

Until the structures of interferons are better understood individually and comparatively so that an informative nomenclature can be devised, I fail to see the wisdom in replacing Roman letters with Greek, in substituting one purely arbitrary system with another equally so, and in abandoning a nomenclature which, at least, has the advantage of familiarity.

LEE H. KRONENBERO

\section{San Diego, California}

\section{Educating scientists}

SIR - I fear that your readers may mistake your report strangely entitled "Subject in search of discipline?"' (Nature 31 July, p.432) for a factual account of Sir Alec Cairncross's report to the Nuffield Foundation on "Science Studies". Nature suggests, not least by the tone of the article, that Cairncross's report is critical of "Science Studies". May I remind you of a major recommendation of the report? Cairncross declares that "There is a

continuing need for injecting into most science degrees some provision for minor courses covering up to 15 per cent of the curriculum. These should be examinable".

This is strangely at odds with what Nature has to say. Nature associates the minor courses to which Cairncross refers with "general chat about the social relations of science", suggests that "Much of what is now provided for students under this heading centres around the much talked of Promethean dilemma" and that "teachers are all too often bent on grinding other axes - political, ideological or religious". These assertions are not drawn from the Cairncross report and neither are they true. They are uncomfortably close to the sorts of uninformed prejudices which many of us involved in serious attempts to serve science education have long struggled to overcome.

Nature expresses itself in favour of the enrichment of science education. 1 am profoundly sorry that it has not chosen to treat more seriously those who believe that they are making some progress towards this end.

C.S. Morphet

\section{Science Technology and}

Society Association,

Newcastle, UK 